\title{
PERANCANGAN VIDEO PROMOSI WISATA KULINER KOTA SEMARANG DALAM PROGRAM “AYO WISATA KE SEMARANG"
}

\author{
${ }^{1)}$ Riska Dwi Noviyanti, ${ }^{2)}$ T. Arie Setiawan, ${ }^{3)}$ Martin Setyawan \\ Fakultas Teknologi Informasi \\ Universitas Kristen Satya Wacana \\ Email: ${ }^{1)}$ riskadwiriska@gmail.com, ${ }^{2)}$ arie.setiawan.p@gmail.com, \\ 3) martin.setyawan@gmail.com
}

\begin{abstract}
Culinary is one type of travelling which is enthused by many tourists, so promotional media is needed to introduce culinary specialties of a city. The government of Semarang established a program called 'Ayo Wisata ke Semarang' to embody the charm of Semarang by discussing the types of Semarang excursions including its culinary. The current media campaigns to promote are certain events along with an extensive duration of video which is seen ineffective. Through these facts, there is a need of a media to support the promotion and gives recommendation of Semarang culinary in the form of a promotional video which introduces the culinary of Semarang using qualitative method and linear strategy to promote Semarang city culinary. The result of the promotional video is published in the official account of Semarang government such as YouTube, Instagram and Facebook.
\end{abstract}

Key words:

Tourism, Culinary Excursion, Ayo Wisata ke Semarang, Promotional, Video

\begin{abstract}
Abstrak
Kuliner merupakan salah satu jenis wisata yang banyak diminati oleh wisatawan, sehingga dibutuhkan media promosi untuk memperkenalkan kuliner yang menjadi ciri khas kota. Pemerintah Kota Semarang membentuk program Ayo Wisata ke Semarang demi mewujudkan pesona wisata dengan membahas jenis wisata di Kota Semarang termasuk wisata kuliner. Media promosi yang sudah ada di Kota Semarang berupa berita melalui video yang dikemas dengan durasi yang panjang dan dirasa kurang efektif. Melalui fakta tersebut, sehingga diperlukan sebuah media untuk mendukung promosi dan memberikan rekomendasi kuliner Kota Semarang berupa video promosi yang lebih memperkenalkan wisata kuliner Kota Semarang dengan menggunakan metode kualitatif dan strategi linier untuk mempromosikan wisata kuliner di Kota Semarang. Hasil video promosi telah dipublikasikan di akun resmi pemerintah Kota Semarang seperti youtube, instagram, dan facebook.
\end{abstract}

Kata Kunci:

Wisata, Kuliner, Ayo Wisata ke Semarang, Video, Promosi 


\section{Pendahuluan}

Sebagai Ibu Kota dari Provinsi Jawa Tengah, Kota Semarang merupakan salah satu Kota yang memiliki keindahan tata kota, dan keindahan dari tempat wisata yang ada di Kota Semarang. Dalam menunjang kepariwisataan, Kota Semarang memiliki fasilitas pendukung seperti adanya program terpadu "Ayo Wisatake Semarang" yang dibentuk oleh PT. Sidomuncul dan diambil alih oleh Dinas Pemerintahan Kota Semarang demi mewujudkan pesona wisata dan meningkatkan jumlah wisatawan Kota Semarang [1].

Dalam program Ayo Wisata ke Semarang terdapat tiga jenis wisata yaitu wisata religi, wisata budaya, dan wisata kuliner. Wisata religi yang meliputi gedung-gedung tempat ibadah dan gedung peninggalan bersejarah, wisata budaya dengan tradisi yang ada di Kota Semarang serta destinasi wisata kuliner yang memiliki ciri khas rasa dan olahan rasa yang menjadikan lumpia, wingko babat, dan bandeng presto sebagai makanan khas dari Kota Semarang[1]. Berdasarkan wawancara dengan Agus Kharis selaku Staff Bidang Pemasaran di Dinas Kebudayaan dan Pariwisata Kota Semarang, program Ayo Wisata ke Semarang merupakan program kedalam dan keluar yang berarti bukan hanya tagline tetapi melalui program ini diharapkan mampu menggugah masyarakat Kota Semarang supaya lebih peduli dan sadar akan potensi kepariwisataan Kota Semarang dan membuat banyak wisatawan luar Kota untuk datang ke Kota Semarang tanpa melupakan kuliner Kota Semarang yang kebanyakan dijadikan buah tangan oleh wisatawan [2]. Berdasarkan data yang diperoleh dari Dinas Kebudayaan dan Pariwisata Kota Semarang, jumlah wisatawan yang datang ke Semarang memiliki tingkat kenaikan yang tidak stabil dikarenakan promosi jenis wisata kurang terpenuhi terkhusus wisata kuliner, sehingga banyak kuliner asli Kota Semarang yang tidak diketahui oleh wisatawan. Media promosi bentuk video yang sudah ada terbilang kurang efektif karena dikemas dengan durasi yang panjang dan dibahas secara keseluruhan untuk jenis wisatanya [3]. Selain itu menurut Hanik Khoiru Solikah selaku Komisi B DPRD Kota Semarang mengatakan bahwa selama ini aspek promosi kurang diperhatikan dan kalaupun ada, itu hanya bersifat untuk melaksanakan kegiatan yang sudah dianggarkan dalam APBD. Bahkan hingga saat ini, upaya promosi yang sudah ada seperti pameran, event besar, melalui surat kabar dan video ayo wisata ke Semarang dengan durasi panjang yang dianggap kurang efektif [1].

Berdasarkan permasalahan yang ada, maka diperlukan media promosi untuk dapat menyampaikan beberapa jenis wisata dari program Ayo Wisata ke Semarang secara efektif pada wisata kulinernya yang dijadikan sebagai buah tangan oleh wisatawan. Media promosi yang dirasa baik adalah sebuah video promosi karena video promosi merupakan media penyampaian pesan yang digunakan untuk mempromosikan, akan menarik jika menggunakan teknik sinematografi yang baik. Sehingga dengan adanya perancangan video promosi wisata kuliner Kota Semarang dalam program Ayo Wisata ke Semarang ini, dapat memberikan rekomendasi perbaikan promosi wisata kuliner di Kota Semarang dan mendukung media promosi yang sudah ada seperti event dan pameran dengan visual yang mudah dipahami oleh masyarakat Kota Semarang dan wisatawan dari luar Kota Semarang. Keunggulan perancangan video promosi ini adalah jenis media promosi yang menarik karena dikemas dengan alur cerita dan sinematografi yang sesuai. Video promosi dapat dijadikan media promosi yang efekif karena audio visual yang jelas dan durasi yang singkat video ini dapat diakses oleh wisatawan melalui akun youtube atau web resmi Pemerintah Kota Semarang, sehingga jenis kuliner di Kota Semarang dapat diketahui oleh wisatawan. 


\section{TinjauanPustaka}

Hasil penelitian yang menjadi referensi adalah skripsi yang berjudul Perancangan Video Promosi Surbaya berupa TVC sebagai Media Promosi Kota Surabaya dengan Mengangkat Pencitraan Sparkling Surabaya, yang disusun oleh Tyas Ajeng Nastiti dan Nugrahardi, S.Sn., Mt. Program Studi Desain Produk Industri Fakultas Teknik Sipil dan Perencanaan di Institut Teknologi sepuluh Nopember, Surabaya. Hasil dari penelitian tersebut adalah adanya sebuah media promosi baru berupa iklan televisi dan video promosi pada TV Billboard yang dimana media promosi TVC (Televisi Commercial) dapat dikatakan lebih mendukung dari pada media promosi jenis cetak seperti iklan pada brosur, iklan di koran dan iklan pada media cetak lainnya [4].

Penelitian yang menjadi referensi kedua adalah thesis dengan judul Persepsi Wisatawan Domestik tentang Unsur-Unsur Pembentuk City Branding Kota Semarang terhadap Minat Berkunjung kembali ke Kota Semarang yang disusun oleh Devi Purnama Sari 14030112410025 program studi Magister Ilmu Komunikasi Fakultas Ilmu Sosial dan Ilmu Politik Universitas Diponegoro Semarang tahun 2014. Hasil dari thesis ini membahas mengenai wisata Kota Semarang dengan penjelasan jumlah wisatawan yang minat datang kembali ke Semarang dan objek wisata yang ada di Kota Semarang [5].

Perancangan Video Promosi Wisata Kuliner Kota Semarang ini memiliki konsep untuk mempromosikan wisata kuliner yang ada di Kota Semarang dengan acuan pada program Ayo Wisata ke Semarang yang akan membahas tentang kebutuhan Bidang 2 DPRD dan Bidang Pemasaran pada Dinas Kebudayaan dan Pariwisata Kota Semarang dengan memberikan media promosi yang efektif dan dikemas menggunakan teknik sinematografi yang tepat. Sehingga dapat memberikan rekomendasi perbaikan wisata kuliner di Kota Semarang.
Video promosi merupakan video yang digunakan untuk mempromosikan sesuatu. Ciri dari video promosi adalah mempromosikan sesuatu secara lebih detail dengan durasi yang lebih penjang dari video iklan karena proses pengambilan gambar untuk video promosi harus dilakukan secara berkala dari objek yang ingin dipromosikan agar hasil dari video promosi tersebut lebih terperinci dan mencakup semua hal yang berhubungan dengan objek tersebut [6].

Media promosi merupakan suatu alat untuk mengkomunikasikan suatu produk/ jasa/ image/ perusahaan ataupun yang lain untuk dapat lebih dikenal masyarakat luas. Media promosi yang paling tua adalah media dari mulut ke mulut. Media ini memang sangat efektif, tetapi kurang efisien karena kecepatan penyampaiannya kurang bisa diukur dan diperkirakan [7].

Sinematografi merupakan kata serapan dari bahasa Inggris Cinematography yang berasal dari bahasa Latin Kinema atau gambar. Sinematografi dikatakan sebagai ilmu terapan yang membahas tentang teknik menangkap gambar dan menggabungkannya sehingga menjadi rangkaian gambar yang dapat menyampaikan suatu ide cerita atau inti dari cerita [8].

Pariwisata dapat dilihat sebagai suatu kegiatan melakukan perjalanan dari rumah dengan maksud tidak melakukan usaha atau bersantai [9].

\section{Metode Penelitian}

Metode yang digunakan dalam penelitian ini adalah menggunakan metodekualitatif. Metode kualitatif adalah suatumetode penelitian yang berlandaskan pada filsafat postpositivisme, digunakan untuk meneliti pada kondisi objek yang alamiah dimana peneliti sebagai instrument kunci, pengambilan sampel sumber data dilakukan secara purposive, teknik pengumpulan dengan triangulasi, analisis data bersifat induktif/kualitatif, dan hasil penelitian 
kualitatif lebih menekankan makna daripada generalisasi [10].

Strategi penelitian yang digunakan adalah strategi penelitian linier yang bergerak per tahap sehingga dapat dikatakan alur maju sebagai dasar dari perancangan video promosi wisata kuliner Kota Semarang. Strategi linier yaitu menetapkan urutan logis pada tahapan perancangan yang sederhana dan relatif sudah dipahami komponennya [11]. Adapun tahaptahap yang digunakan dapat dilihat pada Gambar 1.

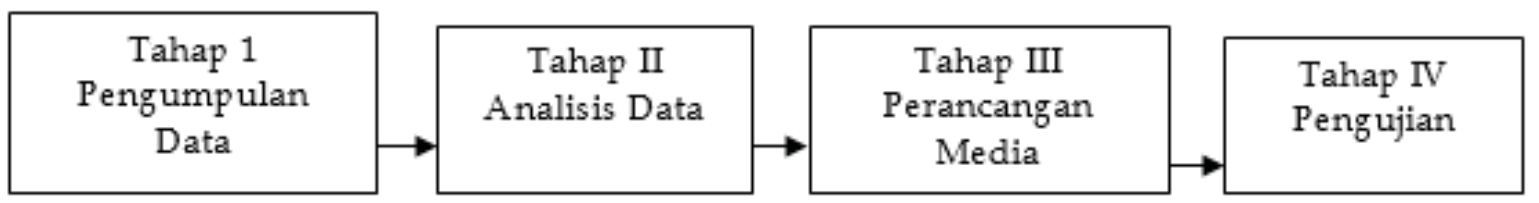

Gambar 1 Tahap Penelitian

Tahap pertama yang dilakukan sebagai langkah awal adalah mengumpulkan data informasi sesuai sumber terkait. Jenis data yang dikumpulkan menjadi dua jenis yaitu data primer dan sekunder. Data primer dikumpulkan melalui observasi dengan melakukan wawancara kepada Bapak Agus Kharis selaku Staff Bidang promosi dari Dinas Kebudayaan dan Pariwisata Kota Semarang mengenai potensi kepariwisataan Kota Semarang yang kurang disadari oleh masyarakat karena kurangnya media promosi yang dikemas secara menarik terutama mengenai kuliner yang sering dijadikan buah tangan [2]. Hasil pada tahap ini adalah promosi wisata kuliner Kota Semarang masih belum maksimal, sehingga banyak wisatawan yang kurang mendapat rekomendasi.

Tahap kedua merupakan tahap analisa data yang dilakukan berdasarkan data wawancara yang telah dikumpulkan. Hasil analisis yang di dapat yaitu perlunya media promosi dalam bentuk video yang dikemas secara singkat, jelas dengan sinematografi yang baik, dimana video promosi yang dikemas efektif mampu mendukung media promosi sebelumnya yang berupa event dan pameran.

Tahap 3 merupakan tahap perancangan media. Pada penelitian ini diperlukan tahapan dalam merancang desain untuk dapat membentuk karakter dari video promosi melalui dua tahapan supaya dapat dilanjutkan pada proses pra-produksi, produksi, dan pasca produksi yang sesuai dengan kebutuhan video promosi wisata kuliner Kota Semarang seperti pada Gambar 2.

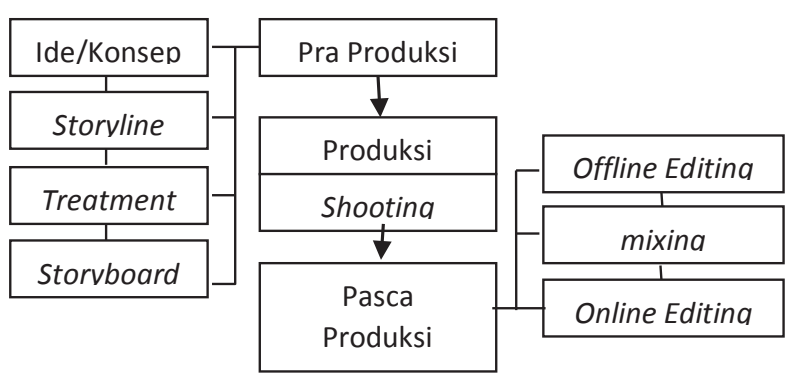

Gambar 2 Bagan Metode Perancangan

Proses yang pertama yaitu proses praproduksi adalah menentukan ide cerita, merancang konsep, membuat skenario alur video, pembuatan storyboard dan menentukan alat-alat yang mendukung supaya pengambilan gambar saat proses produksi berjalan sesuai dengan tahap pra-produksi. Ide cerita dan konsep perancangan video promosi adalah menjelaskan jenis kuliner yang menjadi ciri khas dari Kota Semarang dengan sinematografi yang dikemas secara menarik. Tujuan video promosi supaya dapat memberikan rekomendasi perbaikan promosi wisata kuliner di Kota Semarang dengan visual yang mudah dipahami oleh masyarakat Kota Semarang dan wisatawan 
dari luar Kota Semarang dengan target utama yaitu anak-anak muda yang hanya sekedar mencicipi kuliner bahkan menjadikan buah tangan.

Storyline merupakan kajian yang dirangkai menjadi cerita yang menarik dan merupakan ringkasan atau garis besar alur cerita yang menggambarkan isi dari suatu film atau pementasan yang dilakukan secara umum. Storyline dirancang berdasarkan ide cerita yang sudah direncanakan [8]. Storyline dari video promosi wisata kuliner Kota Semarang adalah menceritakan mengenai letak geografis Kota sebagai Informasi bahwa video promosi yang dibuat di Kota Semarang dengan menunjukkan beberapa ikon yang termasuk ke dalam program Ayo Wisata ke Semarang. Masuk pada bagian wisata kuliner seperti Wingko Babat, Bandeng Presto dan lumpia yang diletakkan pada akhir kuliner karena berdasarkan hasil wawancara dengan Bapak Kharis, lumpia merupakan kuliner yang menjadi ikon dari Kota Semarang. Video promosi ini menggunakan talent di dalam setiap bagian promosi yang berperan sebagai wisatawan dan imbuhan teks dengan jenis font sans serif "bebas" supaya terbaca dengan jelas dan garis yang mengelilingi tulisan untuk menarik fokus mengenai kejelasan nama kuliner dari video promosi

Tahap selanjutnya yaitu treatment. Treatment merupakan sketsa dari sebuah scenario dan menjadi kerangka cerita. Berikut treatment dalam penyusunan video promosi [6].z

Treatment

Scene 1 Opening (Day) : menampilkan Lawang Sewu (long shot,track/ in)

Scene 2 kuliner

: wisatawan membuka pintu (medium shot, follow)

Scene 3 Tahu Gimbal : penyajian tahu gimbal (medium close up, track/ in)

Scene 4 Mie Kopyok : lokasi mie kopyok (long shot, pan-right)
Scene 5 Bandeng Presto : suasana toko (low angle, long shot, track/ in)

Scene 6 Lumpia : : memasak lumpia (medium close up, track/ in)

Scene 7 Lumpia Lanny : lumpia disajikan (full shot, track/in)

Scene 8 Transisi : : transisi sore ke malam (time lapse)

Scene 9 Ikon Kota $\quad$ : kawasan simpang lima (long shot, panright)

Scene 10 Pasar Semawis: keramaian di pasar semawis(full shot, follow)

Scene 11 Soto Semawis : penjual menyajikan (medium shot, long shot)

Scene 12 Tugu Muda : wisatawan berjalanjalan (full shot, follow)

Scene 13 Closing (Night) : tugu muda (ow angle, long shot, track/out)

Berikut adalah Storyboard perancangan video promosi wisata kuliner Kota Semarang yang dapat dilihat pada tabel 1 .

Storyboard adalah sketsa gambar yang disusun berurutan sesuai dengan naskah sehingga menghasilkan persepsi yang sama pada ide cerita. Storyboard the visualflow of narrative is a relatively new concept, but storytelling is not [12].

\section{JNP ${ }_{34}$}


1)Riska Dwi Noviyanti, 2)T. Arie Setiawan, 3) Martin Setyawan, Perancangan Video Promosi Wisata Kuliner Kota Semarang Dalam Program "Ayo Wisata Ke Semarang”

Tabel 1. Storyboard Perancangan Video Promosi Wisata Kuliner Kota Semarang

Durasi
Angle E Shot

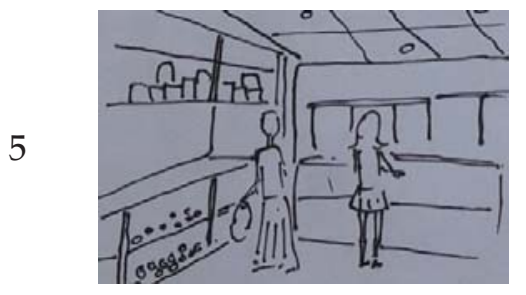

00:00:02 Low angle, long shot, suasana toko

6 00:00:02 full shot, track/in $\begin{aligned} & \text { wisatawan duduk dan } \\ & \text { lumpia disajikan }\end{aligned}$

00:00:05 medium close up, track/in lumpia di atas meja




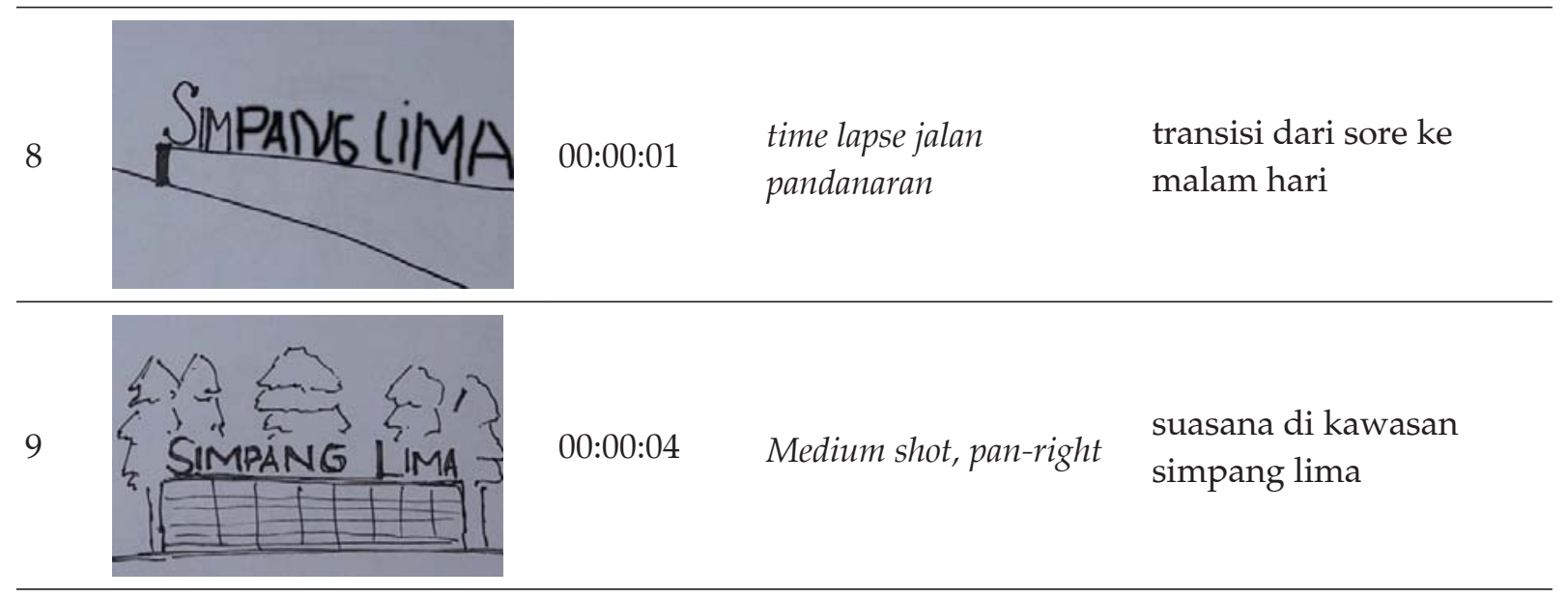

10

11

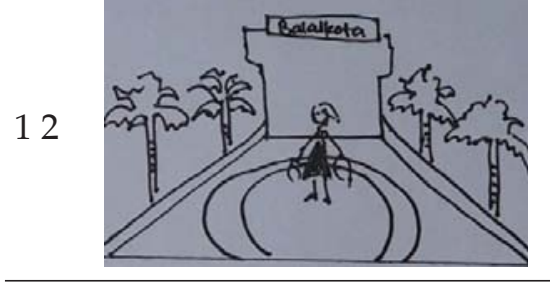

wisatawan berjalan di 00:00:02 full shot, follow depan balaikota dengan senang dan merasa puas

13

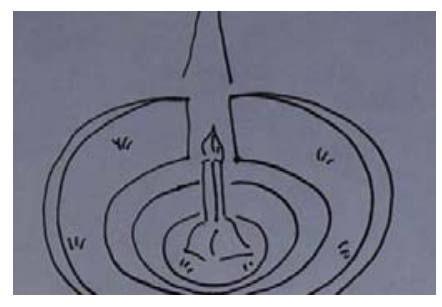

00:00:05 Full shot, track/out

menampilkan kawasan tugu muda di malam hari

Proses yang dilakukan setelah praproduksi adalah produksi atau shooting. Shooting adalah proses pengambilan gambar dalam bentuk video. Shooting dilakukan sesuai dengan rancangan yang telah dibuat dengan tujuan mempersingkat waktu dan biaya yang dikeluarkan. Pengambilan gambar video promosi ini menggunakan beberapa alat yang telah ditentukan karena lokasi yang digunakan adalah indoor dan outdoor.

Tahap setelah produksi yaitu pasca produksi yang dikatakan sebagai proses terkahir. 
Terdapat dua elemen yang melalui tahap pasca produksi, yaitu audio dan video. Pada elemen video memiliki lima dalam yaitu proses Logging, Digitizing, Offline Editing, dan Online Editing. Pada elemen audio dilakukan penyusunan lagu dan pengaturan level atau mixing [6].

Proses logging merupakan proses memotong gambar, mencatat waktu pengambilan gambar dan memilih shot yang sesuai [6]. Proses ini diperlukan kesesuaian file dengan storyboard yang telah dibuat pada tahap pra produksi untuk menata alur pada video. Proses logging dapat dilihat pada Gambar 3.

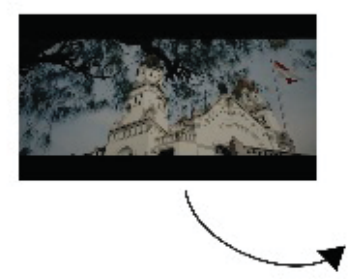

\section{IMPORT KE LEMBAR KERJA} [DRAG AND DROP]

Gambar 3 Proses Logging

Proses selanjutnya adalah proses digitizing. Proses ini merupakan proses memasukkan gambar dan suara yang telah di melewati proses logging [6]. Dimana proses ini dibutuhkan kepekaan untuk menyesuaikan antara gambar dengan audionya. Proses digitizing dapat dilihat pada Gambar 4.

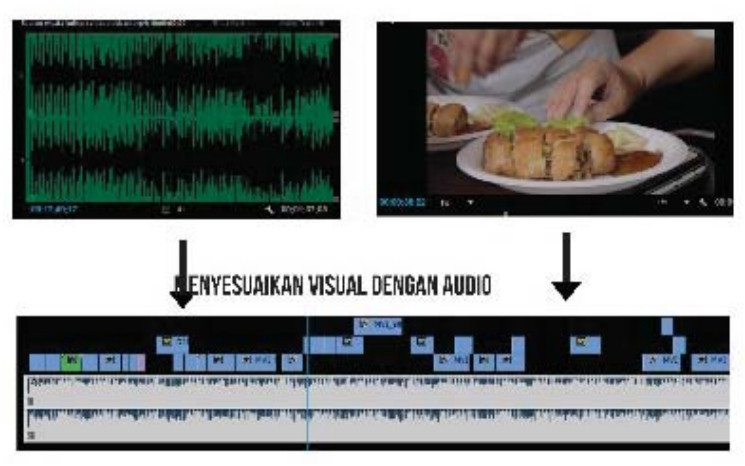

Gambar 4 Proses Digitizing

Setelah proses digitizing dilakukan, proses berikutnya yaitu offline editing. Offline editing merupakan proses menata gambar sesuai dengan scenario dan urutan shot yang telah direncanakan pada tahap pra produksi [6]. Di dalam proses editing terdapat dua metode yaitu linier dan non linier. Perancangan video promosi ini menggunakan metode linier editing karena cerita yang dibangun berdasarkan alur yang berurutan. Proses editing pertama yang dilakukan adalah editing offline Proses offline editing dapat dilihat pada Gambar 5.
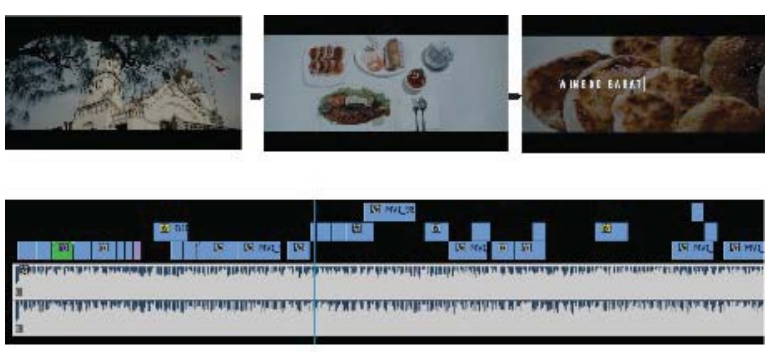

\section{MENATA GAMBAR SESUAI DENGAN STORYBOARD/ALUR CERITA}

Gambar 5 Proses Offline Editing

Setelah melewati proses offline editing, dilanjutkan ke tahap online editing dimana proses online editing adalah untuk memperhalus hasil yang di dapat dari offline, memperbaiki kualitas gambar dan memberikan transisi serta efek yang dibutuhkan [6]. Proses online editing dapat dilihat pada Gambar 6

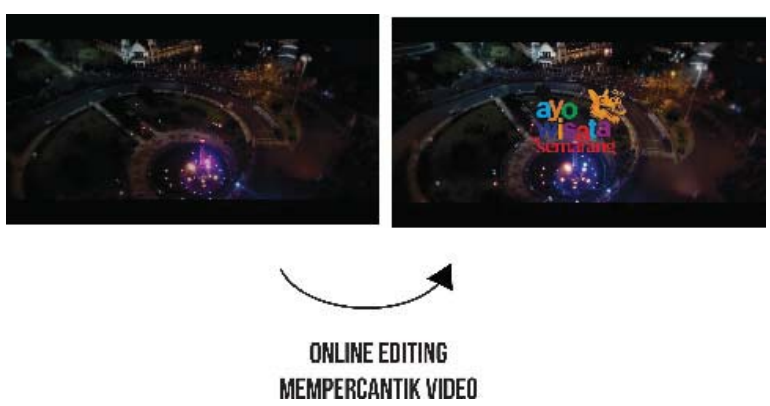

Gambar 6 Proses Online Editing 


\section{Hasil dan Pembahasan}

Video promosi wisata kuliner Kota Semarang ini dibuat berdasarkan program Ayo Wisata Kota Semarang yang berisi beberapa jenis kuliner di Kota Semarang dengan tujuan untuk memberitahukan dan menawarkan suguhan kuliner yang ada di Kota Semarang kepada wisatawan luar sekaligus memberikan rekomendasi jenis promosi wisata kuliner di Kota Semarang. Video Promosi Wisata Kuliner ini dirasa baik karena pengambilan gambar yang menggunakan banyak shot tidak membuat penonton jenuh. Durasi yang singkat membuat penonton mudah memahami dan mengingat jenis wista kuliner yang ada di Kota Semarang.

Pada scene 1 menampilkan gambar lawang sewu yang dapat dilihat pada Gambar 7. Peletakan gambar lawang sewu yang merupakan landmark Kota Semarang di awal video untuk menunjukkan bahwa video yang dibuat yaitu wisata kuliner Kota Semarang. Pengambilan gambar menggunakan jenis medium shot dan low angle untuk membangun suasana bangunan dimana subyek berada sekaligus menciptakan interaksi visual antara subyek dengan gedung lawang sewu. Sedangkan penggabungan panright untuk mempertahankan komposisi visual agar tetap proporsional di dalam frame.

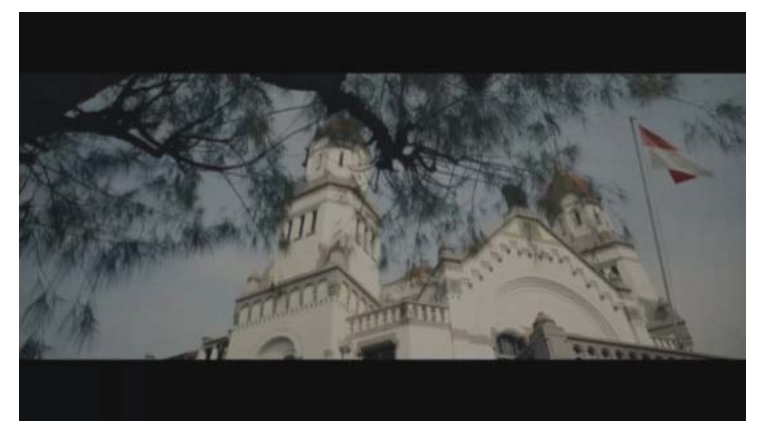

Gambar 7 Visualisasi lawing sewu Kota Semarang

Visualisasi seorang wisatawan masuk ke dalam toko yang menjadi pembuka pada scene 2. Jenis shot yang digunakan adalah medium shot dan follow yang dapat dilihat pada Gambar 8. Medium shot digunakan supaya didapatkan komposisi antara gambar subyek dan gedung secara proporsional.

Follow pan dengan gerakan kamera mengikuti subyek yang bergerak untuk mempertahankan komposisi visual.

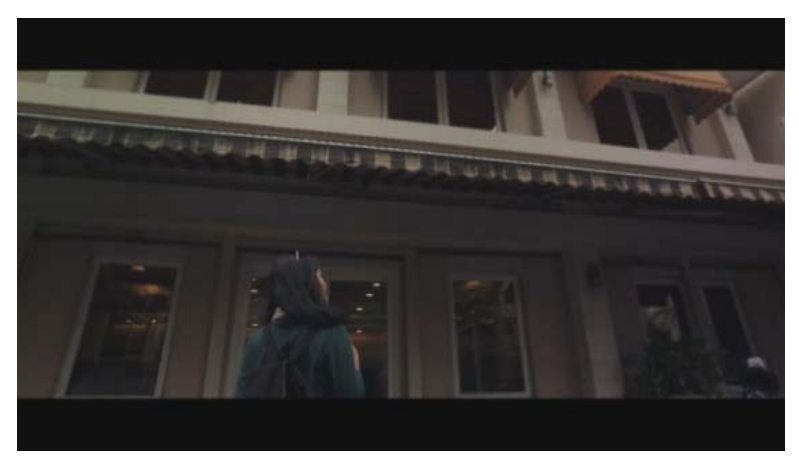

Gambar 8 Wisatawan masuk ke toko oleh-oleh

Wingko babat diletakkan di awal jenis kuliner yang ada dalam video karena wingko babat merupakan kuliner khas Kota Semarang yang ditawarkan kepada wisatawan sebagai buah tangan yang sering dijumpai baik di terminal, stasiun kereta api, pelabuhan bahkan bandara. Pada scene 3 menampilkan visualisasi kuliner wingko babat sebagai pembuka kuliner dalam shot medium close up supaya bentuk dan tekstur pada wingko babat terlihat jelas. Sedangkan penggunakan shot pan-right untuk memperjelas objek wingko babat. Visualisasi scene 3 dapat dilihat pada Gambar 9.

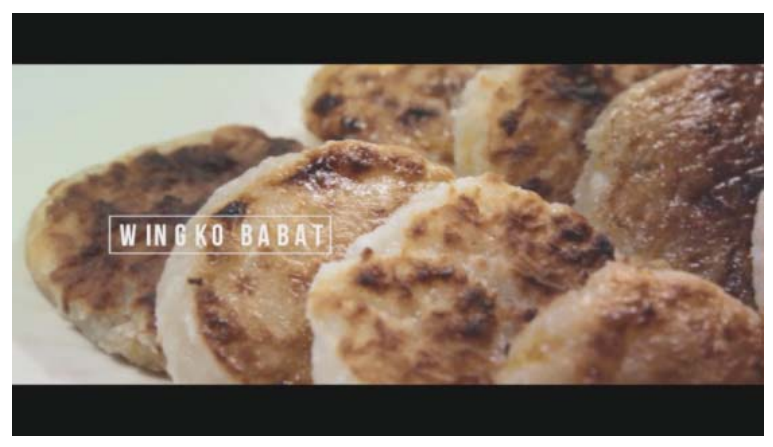

Gambar 9 Wingko Babat 
Scene 4 menampilkan porsi tahu gimbal yang disajikan bersama es duren yang menjadi khas kuliner tahu gimbal di Kota Semarang yang dapat dilihat pada Gambar 10. Jenis shot yang digunakan pada scene 4 adalah medium shot dengan posisi tahu gimbal di tengah frame supaya tahu gimbal tetap menjadi fokus utama pada scene. Sedangkan pengambilan gambar dari atas supaya isi dari tahu gimbal dan es duren dapat terlihat.

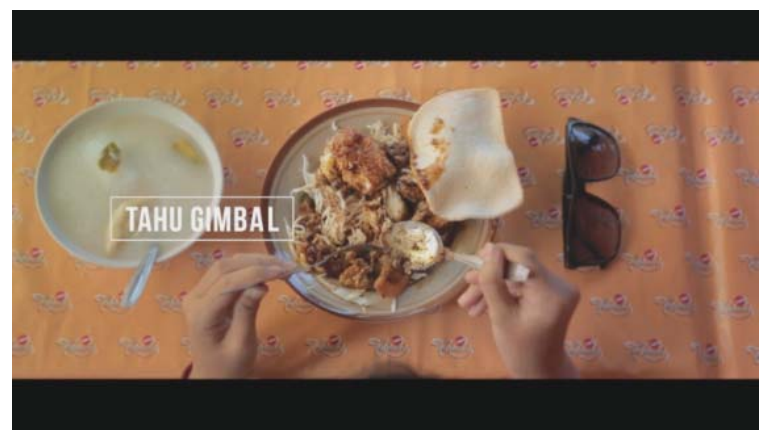

Gambar 10 Tahu Gimbal

Gambar 11 merupakan visualisasi dari scene 5 yang menampilkan seorang wisatawan sedang menikmati hidangan mie kopyok sebagai penggambaran seorang wisatawan yang belum pernah mencoba mie kopyok khas Kota Semarang. Jenis shot yang digunakan pada scene 4 adalah medium shot dengan maksud menunjukkan lebih detail bahasa tubuh dan ekspresi dari subyek ketika sedang menikmati mie kopyok

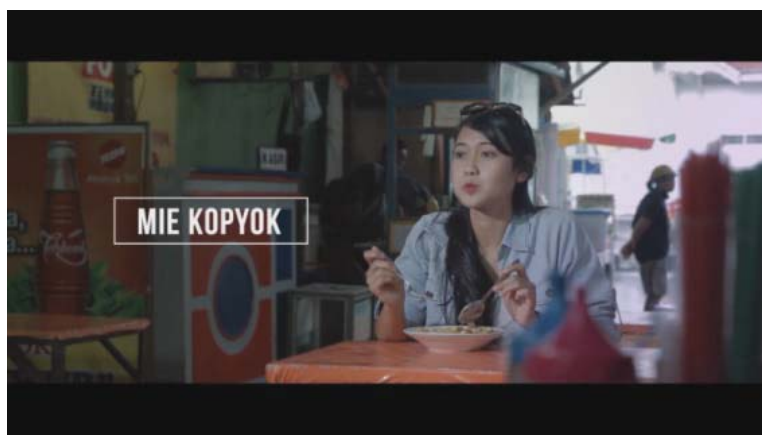

Gambar 11 Mie Kopyok / Mie Lontong
Ikan bandeng presto khas Kota Semarang yang dihidangkan dimeja dengan penggambaran dari beberapa sisi ikan bandeng adalah penggambaran dari scene 6 pada video promosi ini. Jenis shot yang digunakna pada scene ini adalah medium close up dan pan-right. Jenis medium shot digunakan supaya tekstur pada ikan bandeng presto dapat terlihat lebih detail setiap sisinya. Sedangkan penggunaan pan-right bertujuan untuk menghidupkan dimensi pada objek yang dapat dilihat pada Gambar 12.

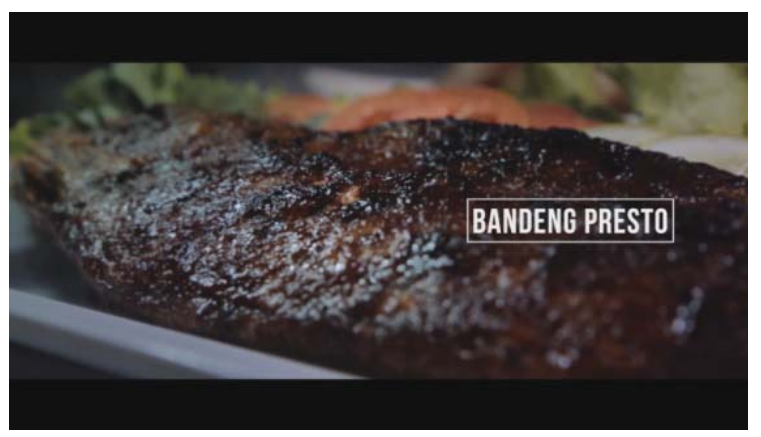

Gambar 12 Bandeng Presto

Sajian lumpia di atas piring dan di tata karena makanan lumpia merupakan kuliner khas yang paling di kenal di Kota Semarang, bahkan sebagai identik Kota Semarang ditampilkan pada scene 7 video promosi kuliner Kota Semarang seperti Gambar 13. Jenis shot yang digunakan adalah medium close up, stay dengan objek yang bergerak supaya visual tetap harmonis.

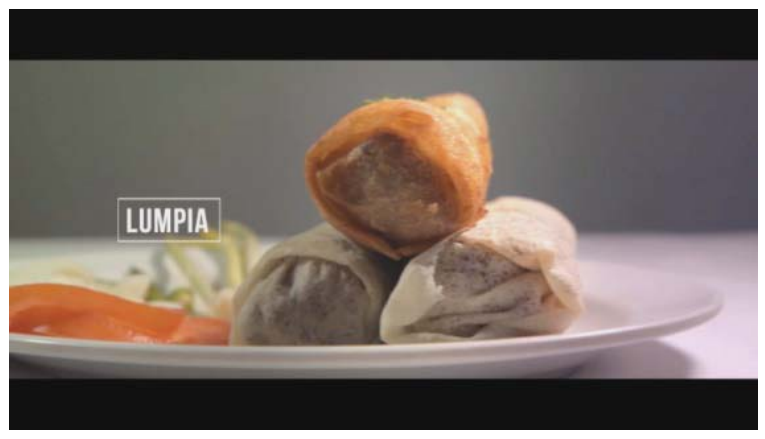

Gambar 13 Lumpia 
Scene 8 pada video promosi yang menampilkan pergantian waktu dengan jenis shot timelapse supaya memberikan visualisasi secara mendetail dalam setiap detik pergantian cahaya ketika sore ke malam hari. Scene 8 dapat dilihat pada Gambar 14.

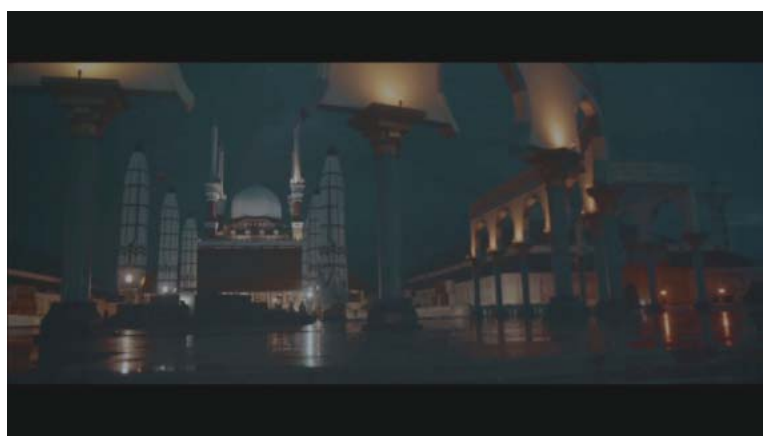

Gambar 14 Transisi pergantian sore ke malam hari

Suasana di Kota Semarang saat malam hari menjadi gambaran dari scene 9 dengan menampilkan kawasan kota lama Semarang saat malam hari. Jenis shot yang digunakan adalah medium shot dan pan-right seperti pada Gambar 15 untuk menunjukkan detail dari setiap suasana yang ada serta menunjukkan suatu pandangan yang lebih luas secara menyeluruh.

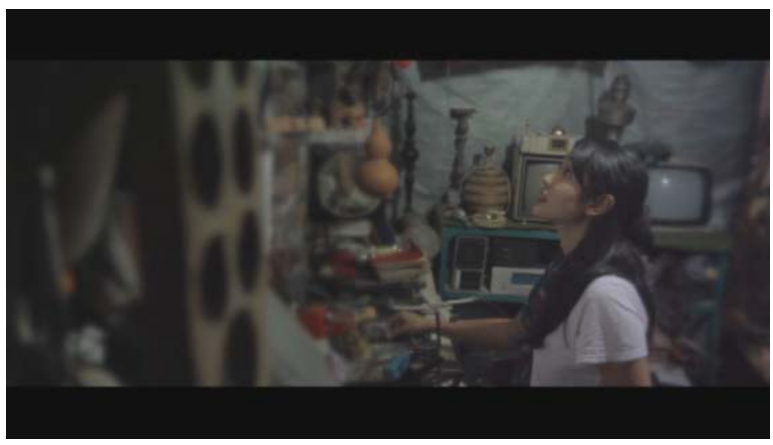

Gambar 15 Suasana di Kota Semarang saat malam hari

Scene 10 menampilkan suasana kuliner di malam hari yaitu di Pasar Semawis. Tempat ini merupakan lokasi pusat kuliner Kota Semarang di malam hari dengan berbagai aneka jajanan yang dapat dilihat pada Gambar 16. Jenis shot yang digunakan adalah full shot supaya memberikan dimensi pada audiens. Pergerakan kamera menggunakan follow untuk menciptakan gambar yang dinamis antara objek dengan background.

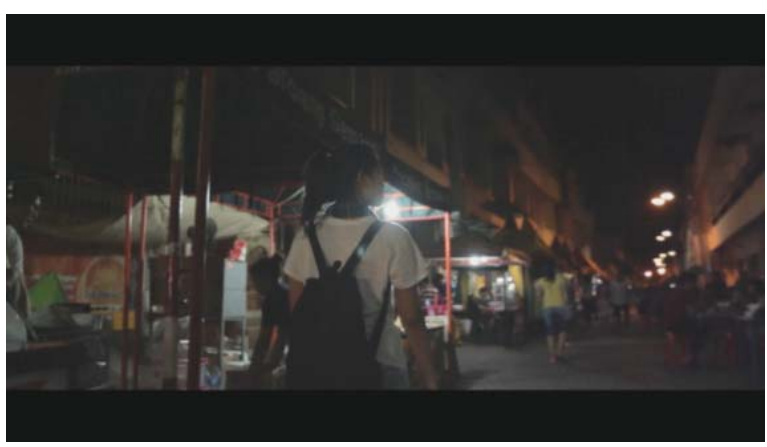

Gambar 16 Suasana pasar semawis

Gambar 17 merupakan scene 11 yang menampilkan seorang wisatawan sedang menikmati soto khas Semarang yang ada di Pasar Semawis. Jenis shot yang digunakan adalah medium long shot, dan stay untuk menunjukkan suasana makan di pasar semawis.

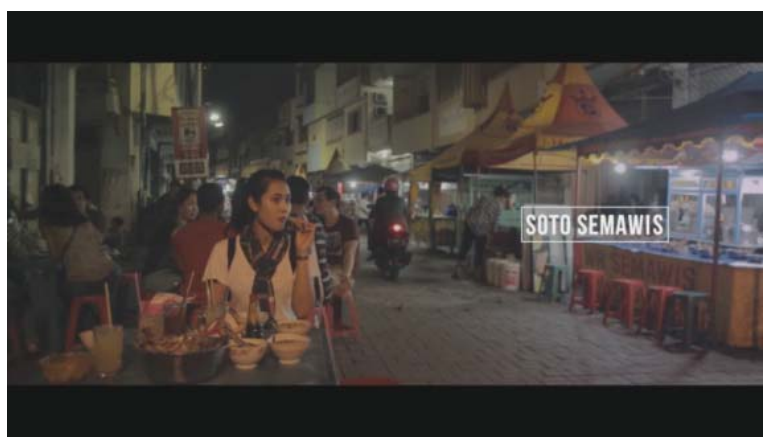

Gambar 17 Soto Semarang yang ada di pasar semawis

Pada video promosi kuliner Kota Semarang menampilkan patung warak sebagai scene 12, karena patung warak merupakan logo identitas dari program ayo wisata ke Semarang. Jenis shot yang digunakan pada scene ini adalah zoom-in dan high angle supaya memperjelas pandangan kepada objek patung warak. Scene 12 dapat dilihat pada Gambar 18. 


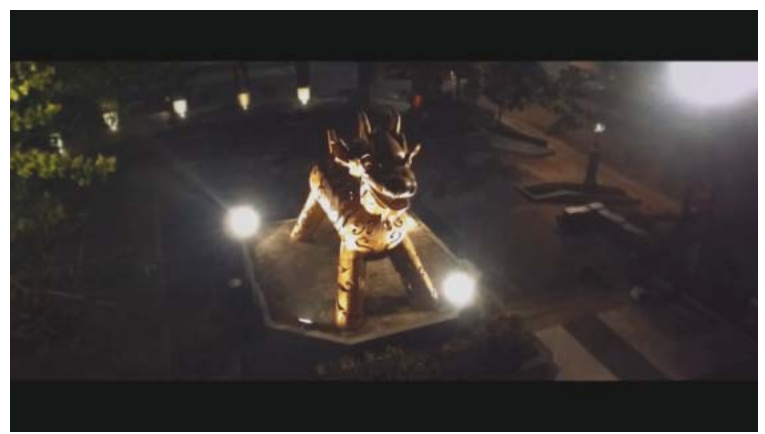

Gambar 18 Patung Warak

Pengambilan gambar landmark Kota Semarang (lawang sewu dan tugu muda) yang diambil menggunakan drone dan high angle dijadikan sebagai penutup video promosi wisata kuliner Kota Semarang sebagai scene 13 dengan maksud memperjelas kembali bahwa video promosi yang dibuat adalah di Kota Semarang. Jenis shot tersebut untuk dapat memvisualisasikan kedua landmark secara luas dan bersamaan dengan menarik dan jelas seperti pada Gambar 19.

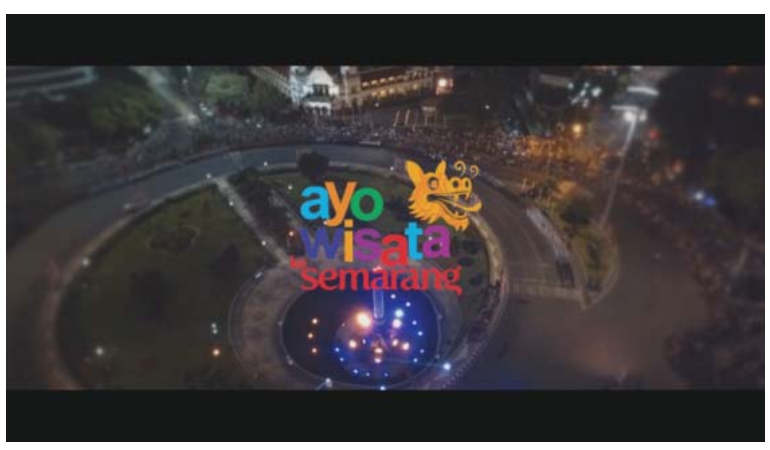

Gambar 19 Landmark Kota Semarang (tugu muda, lawang sewu)

Pengujian video promosi wisata kuliner Kota Semarang dalam program Ayo Wisata ke Semarang menggunakan metode kualitatif. Pengujian pertama dilakukan melalui wawancara kepada Bapak Agus Karis selaku staff bidang pembinaan industri pariwisata Dinas Kebudayaan dan Pariwisata Kota Semarang. Materi yang diujikan kepada Bapak Karis adalah mengenai konten video promosi wisata kuliner Kota Semarang, alur cerita, kecocokan wisata kuliner dengan program dan kebutuhan promosi wisata kuliner berdasarkan program Ayo Wisata ke Semarang untuk publish. Hasil pengujian kepada Bapak Agus Karis mendapatkan hasil bahwa kuliner yang ada sudah sesuai dengan data yang ada pada program Ayo Wisata ke Semarang dan secara umum video promosi kuliner ini memiliki alur cerita yang menarik jika dilihat dari sudut pandang kualitas gambar. Video promosi wisata kuliner dengan durasi yang singkat tetapi dapat menyampaikan pesan dari video promosi kuliner dengan penambahan teks sebagai penjelas nama makanan dirasa efektif untuk memenuhi kebutuhan promosi mengenai wisata kuliner di Kota Semarang sehingga video promosi wisata kuliner dapat publish pada akun resmi pemerintah Kota Semarang.

Pengujian kedua dilakukan dengan Bapak Nana Storada selaku admin dari Pusat Informasi Publik (PIP) Kota Semarang mengenai kelayakan gambar dan susunan cerita, dan konten pada video promosi kuliner Kota Semarang. Berdasarkan pengujian yang telah dilakukan, Bapak Nana Storada mengatakan bahwa video promosi wisata kuliner Kota Semarang sudah memiliki susunan cerita yang rapi dan mudah dipahami oleh penonton yang menjadi target yaitu wisatawan luar Kota Semarang terutama anak muda yang hanya senang mencicipi makanan dari luar kota karena penjelasan jenis makanan yang ada di dalam video cukup menegaskan video ini fokus pada kuliner tanpa mengurangi ikon penting dari Kota Semarang seperti landmark lawang sewu, tugu muda dan patung warak. Menurut Bapak Nana Storada, video ini layak untuk di publish dalam website Pemerintah Kota Semarang untuk sekaligus mendukung program yang ada.

Pengujian ketiga dilakukan wawancara dengan Pandhu Adji Surya selaku Astrada satu pada film layar lebar dengan judul "Turis Romantis" mengenai tatanan sinematografi, jenis shot, kebutuhan promosi, kualitas gambar dan 
kelayakan video untuk publish. Dari pengujian yang dilakukan, didapatkan hasil bahwa video promosi mengenai wisata kuliner Kota Semarang yang telah dirancang sudah memiliki alur sinematografi yang rapi serta jenis shot yang tidak monoton. Pengadeganan dan kualitas gambar yang jelas pada video dapat membantu menarik minat wisatawan untuk mencicipi dan membeli makanan khas Kota Semarang. Kebutuhan promosi pada video promosi wisata kuliner Kota Semarang ini dirasa sudah cukup jelas, menarik dan efektif karena durasi yang tidak begitu panjang, sehingga sudah layak untuk dapat dinikmati wisatawan (publish).

\section{Kesimpulan}

Berdasarkan hasil pengujian yang dilakukan, didapat hasil bahwa perancangan video promosi wisata kuliner Kota Semarang berdasarkan program Ayo Wisata ke Semarang dapat memberikan solusi terhadap masalah kurangnya media promosi yang efektif pada wisata kuliner Kota Semarang dengan memberikan media promosi berupa video promosi wisata kuliner kota Semarang secara efektif dan menarik. Sedangkan untuk Pemerintah Kota Semarang dapat memberikan rekomendasi jenis promosi wisata kuliner untuk mendukung media promosi di Kota Semarang dengan audio dan visual yang mudah dipahami oleh masyarakat Kota Semarang dan wisatawan. Video promosi dengan durasi 2:20 menit dirasa lebih mudah dipahami oleh wisaawan dan telah publish ke dalam akun resmi pemerintah Kota Semarang supaya dapat lebih mudah diakses oleh wisatawan.

\section{Daftar Pustaka}

Ardhi, Yudha. 2013. Merancang Media Promosi Unik \& Menarik. Yogyakarta: Penerbit TAKA Publisher

Brown, Blain. 2013. Cinematography: Theory and Practice. Taylor dan Francis

Hartatik. 2011. 11 November "Ayo Wisata ke Semarang"Dicanangkan.http://www. suaramerdeka.com/v1/index.php/read/ news/2011/10/26/100195/11-November-AyoWisata-ke-Semarang Dicanang-kan. (Diakses 4 Januari 2016)

Karis, Agus. 2016. Wawancara Mengenai Wisata Kuliner Dalam Program "Ayo Wisata Ke Semarang" di Dinas Kebudayaan dan Pariwisata Kota Semarang, Gedung Pandanaran Kota Semarang

Kusmayadu dan Sugiarto, Endar, MM. 2000. Metodologi Penelitian Dalam Bidang Kepariwisataan. Jakarta: PT Gramedia Pustaka Utama

Lintang Mediatama. (2015, Desember 30). AYO WISATA KE SEMARANG. Semarang: Diperoleh dari https://www.youtube. com/watch?v=3YYeaJk-E0I 40:26 menit.

Nastiti, Tyas Ajeng, dan Ramadhani, Nugrahadi. 2013. Perancangan Video Promosi Surabaya Berupa TVC Sebagai Media Promosi Kota Surabaya Dengan Mengangkat Pencitraan Sparkling Surabaya.

Purnama Sari, Devi. 2014. Persepsi Wisatawan Domestik Tentang Unsur-Unsur Pembentuk City Branding Kota Semarang Terhadap Minat berkunjung Kembali Ke Kota Semarang. Semarang: Universitas Diponegoro

Sarwono, Jonathan. 2007. Metode Riset untuk Desain Komunikasi Visual. 
Sugiyono. 2009. Metode Penelitian Kuantitatif fan Kualitatif. Bandung: CV. Alfabeta

Surabaya: Institut Teknologi Sepuluh Nopember

Tumminello, Wendy. 2005. Exploring Storyboarding. Canada: Thomson/ Delmar Learning

Widagdo, M. Bayu dan Winastwan Gora S. 2007. Bikin Film Indie Itu Mudah!. Yogyakarta: Penerbit AndiYogyakarta: CV. Andi Offset 